MaPan : Jurnal Matematika dan Pembelajaran

p-ISSN: 2354-6883 ; e-ISSN: 2581-172X

Volume 7 No 1, June 2019 (136-154)

DOI: https://doi.org/10.24252/mapan.2019v7n1a11

\title{
PENERAPAN MODEL EXPLICIT INSTRUCTION DALAM PEMBELAJARAN MATEMATIKA MATERI BILANGAN ROMAWI PADA SISWA KELAS IV SD INPRES KAPASA MAKASSAR
}

\author{
Agustan Syamsuddin'), Miftahul Jannah ${ }^{2)}$, Kristiawati $^{3)}$ \\ ${ }^{1}$ Magister Pendidikan Dasar, PPs Universitas Muhammadiyah Makassar \\ 2PGSD, FKIP, Universitas Muhammadiyah Makassar \\ 3Pendidikan Matematika, FKIP, Universitas Muhammadiyah Makassar \\ 1,2,3Jl. Sultan Alauddin No. 259, Makassar \\ E-mail: agustan@unismuh.ac.id 1), miftahuljannah@gmail.com²), \\ kristiawati@unismuh.ac.id ${ }^{3}$ )
}

Submitted: 25-06-2019, Revised: 28-06-2019, Accepted: 28-06-2019

\begin{abstract}
Abstrak:
Tujuan penelitian ini untuk mengetahui pengaruh penerapan model explicit instruction terhadap hasil belajar siswa pada materi bilangan Romawi. Penelitian ini merupakan penelitian pra-eksperimen dengan melibatkan 28 siswa kelas IV sebagai sampel di SD Inpres Kapasa. Desain penelitian yang digunakan adalah one-group pretest-posttest design. Berdasarkan hasil analisis data, diperoleh gambaran bahwa: (1) sebelum penerapan model explicit instruction, skor rata-rata hasil belajar siswa yaitu 55,32 yang tergolong kategori rendah, sementara setelah penerapan model explicit instruction skor rata-rata hasil belajar siswa mencapai 83,29 yang tergolong ketegori tinggi; (2) persentase ketuntasan hasil belajar siswa mencapai $92,86 \%$ yang memenuhi kriteria ketuntasan hasil belajar secara klasikal; (3) hasil uji hipotesis diperoleh $t_{\text {hitung }}>t_{\text {tabel }}$ $(4,931>1,703)$ sehingga $\mathrm{H}_{\mathrm{a}}\left(\mathrm{H}_{\mathrm{a}}: \mu_{1}<\mu_{2}\right)$ diterima; (4) diperoleh peningkatan nilai pretest dan posttest dengan indeks gain $(d)$ sebesar 0.62601 yang berada kategori sedang. Berdasarkan hasil penelitian disimpulkan bahwa penerapan model explicit intruction dapat meningkatkan hasil belajar siswa pada materi bilangan Romawi kelas IV SD Inpres Kapasa. Dengan demikian, model explicit instruction merupakan alternatif perbaikan pembelajaran dimana materi bilangan Romawi diajarkan secara tersruktur dan siswa diberi penguatan agar pengetahuan mereka mengendap dan bertahan lama dalam memori.
\end{abstract}

Kata Kunci: Model Explicit Instruction, Bilangan Romawi, Hasil Belajar

\section{IMPLEMENTATION OF THE EXPLICIT INSTRUCTION MODEL IN MATHEMATICAL LERANING ROMAN NUMBER FOR IV GRADE STUDENTS OF SD INPRES KAPASA MAKASSAR}

\begin{abstract}
:
The purpose of this study was to determine the effect of implementing the explicit instruction model towards students' learning outcomes through Roman numeral material. This research was a pre-experimental study involving 28 fourth grade students as a sample in SD Inpres Kapasa. The research design used in this study was one-group pretest-posttest design involving
\end{abstract}


one experimental class which began with a pretest before being given treatment and posttest after being given treatment. Based on the results of the data analysis, it was obtained an illustration that: (1) before the implementation of the explicit instruction model, the average score of student's learning outcomes is 55.32 which was classified as low, while after the application of the explicit instruction model the student's learning outcomes score reaches 83.29 which was classified as high category; (2) the percentage of completeness of student learning outcomes reaches $92.86 \%$ which met the criteria for completeness of learning outcomes in a classical; (3) based on the results of the hypothesis test obtained tcount> ttable (4.931> 1.703) so that $\mathrm{Ha}(\mathrm{Ha}: \mu 1<\mu 2)$ was accepted; (4) obtained an enhancement in the value of the pretest and posttest with the index gain (d) of 0.62601 which was in the medium category. Based on the results of the study concluded that the implementation of the model of explicit instruction can improve learning outcomes of students in the material of Roman numerals in IV grade. Thus, the explicit instruction model is an alternative learning improvement where the material of Roman numbers was taught structurally and students ware given reinforcement so that their knowledge settles and lasts long in memory.

Keywords: Explicit Instruction Model, Roman Number, Learning Outcomes

How to Cite: Syamsuddin, A., Jannah, M., \& Kristiawati. (2019). Penerapan model explicit instruction dalam pembelajaran matematika materi bilangan romawi pada siswa kelas IV SD Inpres Kapasa Makassar. MaPan: Jurnal Matematika dan Pembelajaran, 7(1), 136-154.

\section{PENDAHULUAN}

Tujuan pembelajaran matematika di Sekolah Dasar (SD) adalah menata daya nalar dan membentuk sikap siswa serta memberikan penekanan keterampilan dalam penerapan konsep matematika (Depdiknas, 2011). Hal senada yang juga dijelaskan oleh Susanto (2013) bahwa proses pembelajaran matematika bertujuan untuk mengembangkan kreativitas berpikir siswa, meningkatkan kemampuan mengonstruksikan pengetahuan baru sebagai upaya meningkatkan pemahaman dan penguasaan yang baik terhadap topik matematika. Dalam hal ini, untuk mencapai tujuan tersebut, guru memegang peranan penting sebagai pendidik yang mendampingi siswa.

Dalam pembelajaran matematika di SD, siswa disajikan materi ajar yang meliputi aspek bilangan, geometri dan pengolahan data (Depdiknas, 2011). Cakupan materi bilangan tersebut antara lain bilangan dan angka, perhitungan dan perkiraan. Salah satu materi bilangan yang dibahas dalam pembelajaran matematika di SD adalah bilangan Romawi. Bilangan Romawi merupakan bilangan yang jarang digunakan dalam aktivitas kehidupan sehari-hari. Akan tetapi, bilangan ini dapat kita temukan dalam hal penyusunan dan penomoran bab ataupun sub bab pada buku atau karya tulis ilmiah seperti skripsi, tesis dan 
disertasi ataupun karya tulis ilmiah lainnya. Selain itu, penerapan atau penggunaan bilangan Romawi dapat ditemukan dalam memberikan atau menamai tingkatan kelas, penamaan atau penomoran jalan baik di desa ataupun di kota untuk mempermudah dalam mencari atau mengakses alamat rumah dan lain sebagainya.

Dengan demikian, materi bilangan Romawi juga cukup penting untuk diajarkan kepada siswa. Akan tetapi, dalam menyampaikan materi ini masih banyak kendala yang ditemui dalam pelaksanaannya. Sebagai contoh, siswa masih mengalami kesulitan dalam memahami dan menuliskan lambang bilangan Romawi. Hal ini juga terjadi di SD Inpres Kapasa kota Makassar menunjukkan bahwa dari hasil observasi dan wawancara singkat kepada guru kelas diperoleh informasi bahwa $87.25 \%$ siswa masih mengalami kesulitan dalam memahami dan menuliskan lambang bilangan Romawi. Siswa belum menguasai simbol-simbol dasar bilangan Romawi dan belum paham dalam hal aturan-aturan penempatan bilangan Romawi. Padahal untuk menguasai materi tersebut dibutuhkan pemahaman materi terkait konsep dasar dari materi bilangan Romawi (Syamsuddin, Ernawati \& Syamsi, 2017). Hal tersebut mengindikasikan bahwa bilangan Romawi penting untuk dipelajari dan dipahami oleh siswa.

Sardiman (2011) mengemukakan bahwa pemahaman (understanding) merupakan penguasaan sesuatu dengan pikiran yang ada dalam sistem pembelajaran siswa dan siswa diharapkan mengerti secara mental makna dan filosofinya, maksud dan implikasi serta aplikasinya sehingga menimbulkan kondisi siswa dapat memahami suatu situasi atau konsep yang sedang dipelajari. Dengan demikian dibutuhkan proses pembelajaran yang penuh makna bagi siswa melalui kreativitas guru yang harus bisa dan mampu dalam mengelola pembelajaran dengan baik sesuai dengan karakteristik belajar siswa. Hal demikian perlu dilakukan karena setiap siswa mempunyai karakter yang berbeda-beda atau unik (Widodo \& Kadarwati, 2013).

(Stiff\& Curcio, 1999) dan (Amir, 2018) menjelaskan bahwa siswa memiliki karakteristik yang berbeda dalam belajar dan berpikir untuk menyerap, mengatur dan mengolah informasi. Siswa yang aktif belajar terjadi sebagai akibat dari pengajaran yang menggunakan strategi pembelajaran yang efektif serta pengetahuan guru terkait konten yang diajarkan (Pham, 2011).

Dengan demikian dibutuhkan suatu model pembelajaran yang bisa memberikan penjelasan terkait konten yang diajarkan dengan memperhatikan urutan informasi yang dibutuhkan oleh siswa. Selain itu, model tersebut 
menekankan poin-poin penting atau kesulitan-kesulitan yang mungkin dihadapi siswa. Dengan demikian model pembelajaran tersebut menjadi cara yang efektif untuk mengajarkan konsep serta memungkinkan guru untuk menarik minat siswa dalam menyampaikan materi ajar yang akan dipaparkan.

Salah satu model yang dapat digunakan adalah model pembelajaran explicit instruction dimana model telah diidentifikasi sebagai salah satu model pembelajaran efektif untuk mengajarkan siswa mata pelajaran matematika (National Mathematics Advisory Panel, 2008). Model explicit instruction merupakan model pembelajaran yang dirancang secara khusus untuk mengembangkan aktivitas belajar siswa yang berkaitan dengan aspek pengetahuan prosedural (pengetahuan tentang bagaimana melaksanakan sesuatu) dan pengetahuan deklaratif (pengetahuan tentang sesuatu yang berupa fakta, konsep, atau generalisasi) yang terstruktur dengan baik dan dapat dipelajari selangkah demi selangkah (Darch, Gerten \& Gersten, 1984).

Model pembelajaran explicit instruction ini dapat digunakan pada pembelajaran matematika materi bilangan Romawi karena dalam pengajaran materi bilangan Romawi harus diajarkan secara terstruktur dan harus diberi penguatan agar mengendap dan bertahan lama dalam memori siswa. Hal tersebut sesuai dengan hasil penelitian (Pujiyati, 2017) yang menyatakan bahwa mengajarkan suatu konten atau konsep matematika secara terstruktur dapat dilakukan dengan menerapkan model pembelajaran explicit instruction. Terkait pembelajaran matematika, (Susanto, 2013) mengemukakan bahwa proses pembelajaran matematika yang dibangun oleh guru dalam mengembangkan kreativitas berpikir siswa, meningkatkan kemampuan mengonstruksikan pengetahuan baru sebagai upaya meningkatkan pemahaman dan penguasaan yang baik terhadap topik matematika.

Hal senada yang diungkapkan oleh Heruman (2012) bahwa dalam pembelajaran matematika, setiap konsep yang abstrak yang baru dipahami siswa perlu segera diberi penguatan agar mengendap dan bertahan lama dalam memori siswa sehingga akan melekat pada pola pikir dan pola tindakannya. Selanjutnya, Fatimah (2009) menyatakan bahwa pembelajaran matematika membentuk logika berpikir bukan sekedar pandai berhitung. Dengan demikian, model ini dapat memberi penguatan terhadap konsep matematika yang dipelajari oleh siswa yang berimbas pada peningkatan pemahaman dan hasil belajar matematika siswa (Putri \& Afrom, 2018; Darmiyati \& Hasanah, 2018). 
Melalui model explicit instruction ini, materi bilangan Romawi akan diajarkan kepada siswa secara berurutan atau sistematis mulai dari pengenalan angka dasar bilangan Romawi, bagaimana cara membaca dan bagaimana cara menuliskan bilangan Romawi serta aturan-aturan dalam bilangan Romawi. Selain itu, untuk mengetahui tingkat pemahaman siswa terkait materi yang disajikan maka guru juga memberikan latihan dan membimbing proses penyelesaian soal latihan siswa serta memberikan latihan secara mandiri.

\section{METODE PENELITIAN}

Penelitian ini merupakan penelitian pre-eksperimen, melibatkan satu kelas eksperimen tanpa adanya kelas lain sebagai kelompok pembanding (kelas kontrol) dengan tujuan untuk mendapatkan gambaran pengaruh penggunaan atau penerapan model pembelajaran explicit instruction terhadap hasil belajar matematika siswa pada materi bilangan Romawi. (Fraenkel \& Wallen, 2003) mengistilahkan desain penelitian ini dengan weak eksperimental design. Adapun desain eksperimen penelitian yang digunakan pada penelitian ini adalah onegroup pretest-posttest design dimana penelitian diawali dengan pretest sebelum diberikan perlakuan dan posttest setelah diberikan perlakuan berupa penerapan model pembelajaran explicit instruction. Adapun desain penelitian yang dimaksudkan dalam penelitian ini adalah:

\begin{tabular}{ccc}
\hline O & X & O \\
Pretest & Treatment & Posttest \\
\hline & & (Fraenkel, J. R., \& Wallen, 2003)
\end{tabular}

Keterangan :

$\mathbf{O}_{1}=$ hasil belajar siswa sebelum diajar menggunakan model pembelajaran explicit instruction (pre-test).

$\mathbf{X}=$ mengajar materi bilangan Romawi dengan menggunakan model pembelajaran explicit instruction.

$\mathrm{O}_{2}=$ hasil belajar siswa setelah diajar menggunakan model pembelajaran explicit instruction (post-test).

Penelitian ini melibatkan 28 siswa sebagai sampel penelitian. Sampel dipilih dengan menggunakan teknik random sampling dimana siswa kelas IV SD Inpres Kapasa Kota Makassar tahun ajaran 2018-2019 berjumlah 57 orang yang dibagi menjadi dua kelas paralel yaitu kelas IV A dan IV B dengan rincian sebagai berikut: 
Tabel 1. Keadaan Siswa Kelas IV SD Inpres Kapasa

\begin{tabular}{|c|c|c|c|}
\hline Kelas & Laki-Laki & Perempuan & Jumlah Siswa \\
\hline IV A & 11 & 18 & 29 \\
\hline IV B & 12 & 16 & 28 \\
\hline \multicolumn{3}{|c|}{ Jumlah } & 57 \\
\hline
\end{tabular}

Sumber: SD Inpres Kapasa 2018/2019

Berdasarkan hasil pengundian yang dilakukan, peneliti memilih kelas IV B sebagai sampel penelitian. Instrumen yang digunakan untuk mengumpulkan data penelitian berupa tes hasil belajar matematika yang berkaitan dengan tes kemampuan berhitung pada materi bilangan Romawi. Instrumen ini berbentuk soal uraian yang terdiri atas 10 butir dan disusun berdasarkan indikator dan tujuan pembelajaran.

Untuk mengetahui instrumen ini dapat mengukur kemampuan berhitung pada materi bilangan Romawi, maka perlu dilakukan uji validitas dan reliabilitas. Pada penelitian ini, uji validitas yang digunakan adalah uji validitas isi (content validity) dan validitas butir soal (item validity). Validitas isi berkaitan dengan sejauh mana instrumen ini mengukur tingkat penguasaan terhadap materi bilangan Romawi. Basuki \& Haryanto (2014) menyatakan bahwa validasi isi bertujuan untuk menilai kemampuan tes mempresentasikan dengan baik ranah yang hendak diukur. Lebih lanjut, Basuki \& Haryanto (2014) menyatakan bahwa agar instrumen penelitian memiliki isi yang baik harus dilakukan penelaahan dan pembuatan kisi-kisi soal. Penelaahan dan pembuatan kisi-kisi mencakup butir-butir soal dan penyusunan indikatorindikator soal sehingga tidak ada indikator yang terlewatkan.

Sementara, untuk validitas butir soal dilakukan dengan uji coba secara empiris. Pengujian validitas butir soal dilakukan dengan melakukan uji coba instrumen yang telah dikembangkan kepada 15 siswa kelas IV SD Kapasa, kemudian menghitung koefisien validitas dengan menggunakan rumus koefisien korelasi product moment (Ratumanan \& Laurens, 2011) dengan simpangan sebagai berikut.

$$
r_{x y}=\frac{\sum x y}{\sqrt{\left(\sum x^{2}\right)\left(\sum y^{2}\right)}}
$$


Kriteria yang digunakan peneliti untuk menentukan kriteria validitas instrumen penelitian ini disajikan pada tabel 2 berikut.

Tabel 2. Kriteria Validitas Instrumen

\begin{tabular}{cc}
\hline $\begin{array}{c}\text { Koefisien } \\
\text { Validitas }\end{array}$ & Penafsiran \\
\hline$r \leq 0,00$ & Tidak valid \\
$0,00<r \leq 0,20$ & Validitas sangat rendah \\
$0,20<r \leq 0,40$ & Validitas rendah \\
$0,40<r \leq 0,60$ & Validitas sedang \\
$0,60<r \leq 0,80$ & Validitas tinggi \\
$0,80<r \leq 1,00$ & Validitas sangat tinggi \\
\hline
\end{tabular}

(Ratumanan \& Lauran, 2011)

Berdasarkan hasil perhitungan koefisien validitas instrumen penelitian ini diperoleh nilai koefisien validitas sebesar 0.785076. Dengan demikian dapat diinterpretasikan bahwa instrumen hasil belajar yang dianalisis memiliki validitas kriterium dengan kategori tinggi.

Untuk validitas butir soal meliputi tingkat kesukaran, daya pembeda dan korelasi antara skor butir soal dengan skor total soal (Basuki \& Haryanto, 2014). Dikarenakan instrumen tes adalah soal essay maka untuk menghitung tingkat kesukaran menggunakan rumus (Ramineni \& Williamson, 2013) sebagai berikut

$$
P_{j}=\frac{\sum_{i=1}^{n} f_{i} X_{i}-n X_{\min }}{n\left(X_{\max }-X_{\min }\right)}, \forall i \in N
$$

(University of Iowa , 2014).

Keterangan:

$\sim f_{i} X_{i}$ : hasil perkalian antara nilai per butir soal dengan jumlah responden yang mendapatkan nilai itu

$X_{\max }$ : nilai tertinggi

$X_{\min }:$ nilai terendah

$n \quad$ : banyaknya responden

Kriteria yang digunakan peneliti untuk menentukan indeks kesukaran instrumen pada penelitian ini disajikan pada tabel 3 berikut. 
Tabel 3. Kriteria Indeks Kesukaran Butir Soal

\begin{tabular}{cc}
\hline Indeks Kesukaran & Kategori \\
\hline$p<0,25$ & Sukar \\
$0,25 \leq p<0,75$ & Sedang \\
$75<p$ & Mudah \\
\hline
\end{tabular}

(Ratumanan \& Laurens, 2011)

Hasil perhitungan indeks kesukaran tes kemampuan matematika pada penelitian ini memiliki kecenderungan soal tes yang berada pada kategori sedang dengan rincian masing-masing 1 nomor yang berada pada kategori mudah dan sukar, sementara 8 nomor yang berada pada kategori sedang.

Berdasarkan hal tersebut, dapat disimpulkan bahwa soal tes instrumen yang digunakan sudah valid karena instrumen ini soalnya cenderung berada pada kategori sedang. Selanjutnya, untuk daya pembeda dari instrumen yang telah dikembangkan menggambarkan kemampuan suatu butir soal dapat membedakan antara siswa yang sudah menguasai materi dengan siswa yang belum menguasai materi dengan baik. Rumus yang digunakan untuk menghitung daya pembeda (University of Iowa, 2014) adalah sebagai berikut.

$$
P_{U}=\frac{\sum_{i=1}^{n} f_{U} X-n\left(X_{\min }\right)}{n\left(X_{\max }-X_{\min }\right)}
$$

dan

$$
P_{L}=\frac{\sum_{i=1}^{n} f_{L} X-n\left(X_{\min }\right)}{n\left(X_{\max }-X_{\min }\right)}
$$

Keterangan:

$P_{U} \quad$ : Proporsi responden kelompok atas

$P_{L} \quad$ : Proporsi responden kelompok bawah

$f_{U} \quad$ : Frekuensi kelompok atas

$f_{L} \quad$ : Frekuensi kelompok bawah

Untuk menentukan daya pembedanya maka dihitung menggunakan rumus $D=P_{U}-P_{L}$ (University of Iowa, 2014). Kriteria yang digunakan peneliti untuk menentukan daya pembeda instrumen disajikan pada tabel 4 . 
Tabel 4. Kriteria Indeks Daya Beda

\begin{tabular}{cc}
\hline $\begin{array}{c}\text { Indeks Daya } \\
\text { Pembeda }\end{array}$ & Kategori \\
\hline $0,40 \leq D$ & Butir sangat baik \\
$0,30 \leq D<0,40$ & Butir baik \\
$0,20 \leq D<0,30$ & Butir cukup \\
$D<0,20$ & Butir jelek \\
\hline
\end{tabular}

(Ratumanan \& Laurens, 2011)

Hasil perhitungan daya beda tes hasil belajar matematika siswa pada penelitian ini berada pada kategori cukup (butir soal no. 5 dan 9), baik (butir soal no. 1, 6 dan 8) dan sangat baik (butir soal no. 2, 3, 4, 7 dan 10) sehingga soal tes tersebut dikatakan valid.

Selanjutnya, mengkorelasikan skor tiap butir dengan skor total yang merupakan jumlah tiap skor butir. Pada penelitian ini, perhitungan koefisien korelasi digunakan untuk mengukur tingkat validitas butir soal apakah butir soal tersebut layak digunakan atau tidak. Dalam menentukan layak atau tidaknya suatu butir soal, biasanya digunakan uji signifikansi valid jika berkorelasi signifikan terhadap skor total. Hasil perhitungan korelasi antara skor butir soal dengan skor total soal berada pada kategori valid.

Berdasarkan hasil perhitungan validitas butir soal yang meliputi tingkat kesukaran, daya pembeda dan korelasi antara skor butir dengan skor soal maka diperoleh kriteria butir soal disajikan pada tabel 5 berikut.

Tabel 5. Kriteria Butir Soal

\begin{tabular}{ccccc}
\hline Butir soal & $\begin{array}{c}\boldsymbol{p} \\
\text { (Indeks } \\
\text { Kesukaran) }\end{array}$ & $\begin{array}{c}\boldsymbol{D} \\
\text { (Daya } \\
\text { Beda) }\end{array}$ & $\begin{array}{c}\boldsymbol{r}_{\boldsymbol{i x}} \\
\text { (Korelasi } \\
\text { Item-i } \\
\text { dengan Skor } \\
\text { Total) }\end{array}$ & $\begin{array}{c}\text { Status } \\
\text { Butir Soal }\end{array}$ \\
\hline 1 & 0,90 & 0,4 & 0,652 & Diterima \\
2 & 0,60 & 0,5 & 0,590 & Diterima \\
3 & 0,53 & 0,54 & 0,644 & Diterima \\
4 & 0,47 & 0,5 & 0,548 & Diterima \\
5 & 0,57 & 0,3 & 0,593 & Diterima \\
6 & 0,67 & 0,4 & 0,611 & Diterima \\
7 & 0,50 & 0,5 & 0,667 & Diterima \\
8 & 0,63 & 0,4 & 0,567 & Diterima \\
9 & 0,50 & 0,3 & 0,667 & Diterima \\
10 & 0,23 & 0,5 & 0,632 & Diterima \\
\hline
\end{tabular}


Dari Tabel 5. di atas dapat dijelaskan bahwa hasil uji validitas dari instrumen menunjukkan bahwa intrumen tersebut valid dan layak untuk digunakan. Untuk pengujian reliabilitas instrumen, peneliti menggunakan rumus Alpha sebagai berikut.

$$
\alpha=r_{11}=\left[\frac{n}{(n-1)}\right]\left[1-\frac{\sum s_{i}{ }^{2}}{s_{t}{ }^{2}}\right]
$$

Keterangan:

$\alpha=r_{11}:$ koefisien realibilitas

$n \quad$ : Banyaknya butir

$\sum s_{i}{ }^{2} \quad$ : Jumlah varians skor setiap butir

$s_{t}{ }^{2} \quad$ : Varians skor total

Nilai $\alpha$ atau $r$ yang diperoleh pada perhitungan dengan menggunakan rumus koefisien Alpha atau Alpha Cronbach di atas memiliki kriteria reliabilitas instrumen seperti disajikan pada Tabel 6 berikut.

Tabel 6. Kriteria Reliabilitas Instrumen

\begin{tabular}{cc}
\hline Koefisien & Penafsiran \\
Realibilitas & Derajat realibilitas tinggi \\
$0,80<r$ & Derajat realibilitas sedang \\
$0,40 \leq r \leq 0,80$ & Derajat realibilitas rendah \\
$r<0,40$ & \\
\hline
\end{tabular}

(Ratumanan \& Laurens, 2011)

Pada penelitian ini, kriteria reliabilitas instrumen yang digunakan untuk menentukan instrumen tes hasil belajar reliabel atau tidak adalah minimal pada kategori sedang $(0,40 \leq \mathrm{r}<0,80)$. Apabila reliabilitas yang diperoleh adalah rendah maka instrumen tes hasil belajar matematika siswa akan direvisi. Berdasarkan kriteria reliabilitas instrumen pada Tabel 9. di atas, hasil perhitungan koefisien reliabilitas instrumen penelitian ini memiliki derajat reliabilitas pada kategori sedang yaitu 0,597.

Data yang diperoleh dari hasil pengumpulan data melalui instrumen tes hasil belajar tersebut yang berupa pretest dan postest pada materi bilangan Romawi dengan model pembelajaran explicit instruction selanjutnya dianalisis dengan menggunakan teknik analisis deskriptif dan inferensial. Analisis statistik deskriptif digunakan untuk mendeskripsikan hasil belajar matematika 
yang diperoleh siswa sebelum diajar dan setelah diajar dengan menggunakan model pembelajaran explicit instruction pada materi bilangan Romawi. Untuk kepentingan tersebut, maka dilakukan perhitungan rata-rata tentang hasil belajar siswa (Sudjana, 2012) setelah mengikuti pelajaran matematika materi bilangan Romawi, dengan rumus:

$$
\bar{x}=\frac{\sum x}{N}
$$

Keterangan:

$$
\begin{array}{ll}
\bar{x} & =\text { Nilai rerata } \\
\sum x & =\text { Jumlah } \\
N & =\text { Banyaknya subjek }
\end{array}
$$

Hasil belajar sebelum dan sesudah dengan model pembelajaran explicit instruction dianalisis dengan teknik analisis presentase (Sudijono, 2010) dengan rumus sebagai berikut:

$$
P=\frac{f}{N} \times 100 \%
$$

\section{Keterangan:}

$\mathrm{P} \quad=$ Persentase

$\mathrm{f} \quad=$ Frekuensi yang dicari persentasenya

$\mathrm{N} \quad=$ Jumlah subjek eksperimen

Selanjutnya untuk kategori hasil belajar siswa digunakan teknik kategori standar yang ditetapkan oleh (Depdiknas, 2009) sebagai berikut:

Tabel 7. Kategori Hasil Belajar Siswa

\begin{tabular}{cc}
\hline Interval Nilai & Kategori \\
\hline $85-100$ & Sangat Tinggi \\
$65-84$ & Tinggi \\
$55-64$ & Sedang \\
$35-54$ & Rendah \\
$0-34$ & Sangat Rendah \\
\hline
\end{tabular}

Hasil belajar matematika siswa juga diarahkan pada pencapaian hasil belajar secara individual dan klasikal. Kriteria seorang siswa dikatakan tuntas apabila memiliki nilai paling sedikit 70 dari skor ideal 100 sesuai dengan KKM (kriteria ketuntasan minimal) yang telah ditetapkan oleh pihak sekolah, sedangkan ketuntasan klasikal tercapai apabila minimal 75\% siswa di kelas tersebut telah mencapai skor paling sedikit 65 . 
Statistik inferensial digunakan untuk menguji hipotesis yang telah diajukan dengan menggunakan uji-t berkorelasi uji pihak kiri. Berikut teknik pengujian uji-t dengan $\alpha=0,05$ (Sugiyono, 2010).

$$
t=\frac{M d}{\sqrt{\frac{\sum X^{2} d}{N(N-1)}}}
$$

Keterangan :

$\mathrm{t}$

Md $=$ mean dari perbedaan pretest dengan posttest

$\sum X^{2} d \quad=$ jumlah kuadrat deviasi

$N \quad=$ jumlah sampel

Selanjutnya, untuk mengetahui peningkatan nilai pretest dan posttest maka dilakukan perhitungan indeks gain. Dalam penelitian ini, indeks gain akan digunakan apabila rata-rata nilai sebelum dan setelah perlakuan berbeda. Rumus indeks gain (d) adalah sebagai berikut:

$$
\operatorname{gain}(d)=\frac{o_{1-} o_{2}}{\text { skor maksimum yang mungkin }-o_{1}}
$$

Keterangan :

$\mathrm{O}_{1} \quad=$ hasil pengukuran pretest

$\mathrm{O}_{2} \quad=$ hasil pengukuran posttest

Tabel 8. Kriteria Interpertasi Indeks Gain

\begin{tabular}{cc}
\hline Besarnya "d" Gain & Interpretasi \\
\hline$d>0,7$ & Tinggi \\
$0,3 \leq d<0,7$ & sedang \\
$d<0,3$ & rendah \\
\hline
\end{tabular}

(Hake, 1999)

Untuk keperluan pengujian hipotesis di atas digunakan uji pihak kiri dan dirumuskan sebagai berikut:

$$
H_{0}: \mu_{1} \geq \mu_{2} \text { dan } H_{a}: \mu_{1}<\mu_{2}
$$

$H_{0}=$ Rata-rata hasil belajar pretest siswa lebih besar atau sama dengan rata-rata hasil belajar posttest siswa.

$H_{a}=$ Rata-rata hasil belajar pretest siswa lebih kecil dari rata-rata hasil belajar posttest siswa. 


\section{HASIL PENELITIAN DAN PEMBAHASAN}

Dari instrumen hasil belajar matematika siswa pada materi bilangan Romawi yang telah dikembangkan, selanjutnya digunakan untuk mengambil data penelitian. Pada kegiatan pretest yaitu tes yang dilakukan sebelum diterapkan model pembelajaran explicit instruction diperoleh gambaran hasil penelitian secara detail dideskripsikan pada tabel 9 berikut.

Tabel 9. Deskripsi Hasil Belajar Siswa pada Kegiatan Pretest dan Posttest

\begin{tabular}{ccc}
\hline Kategori Nilai Statistik & Pretest & Posttest \\
\hline Jumlah Siswa & 28 & 28 \\
Nilai Tertinggi & 85 & 100 \\
Nilai Terendah & 20 & 65 \\
Nilai Rata-rata & 55,32 & 83,29 \\
Standar deviasi & 17,32 & 11,87 \\
\hline
\end{tabular}

Berdasarkan tabel di atas terlihat bahwa setelah penerapan model pembelajaran explicit instruction tampak nilai maksimum hasil belajar siswa pada kegiatan posttest adalah 100 dan skor terendah adalah 65. Rata-rata skor yang diperoleh adalah 83,29 dengan standar deviasi 11,87. Jika dibandingkan dengan kegiatan prestest nilai maksimum hanya berada pada poin 85 dan skor terendah mencapai 20. Sementara rata-rata hasil belajar hanya berada pada rerataan 55,32 dengan standar deviasi 17,32.

Selanjutnya dilakukan analisis terkait kategori hasil belajar siswa yang dijabarkan secara detail pada tabel 10 berikut.

Tabel 10. Deskripsi Kategori Hasil Belajar Siswa pada Pretest dan Posttest

\begin{tabular}{cccccc}
\hline Interval & \multirow{2}{*}{ Kategori } & \multicolumn{2}{c}{ Pretest } & \multicolumn{2}{c}{ Posttest } \\
\cline { 3 - 6 } & & f & $\mathbf{\%}$ & f & $\mathbf{\%}$ \\
\hline $0-34$ & Sangat Rendah & 4 & 14,29 & 0 & 0 \\
$35-54$ & Rendah & 8 & 28,57 & 0 & 0 \\
$55-64$ & Sedang & 6 & 21,43 & 2 & 7,14 \\
$65-84$ & Tinggi & 9 & 32,14 & 15 & 53,57 \\
$85-100$ & Sangat Tinggi & 1 & 3,57 & 11 & 39,29 \\
\hline & Jumlah & 28 & 100 & 28 & 100 \\
\hline
\end{tabular}

Tabel di atas menunjukkan bahwa nilai postest siswa setelah diterapkan model pembelajaran explicit instruction tidak ada yang berada pada kategori sangat rendah dan rendah. Sementara pada kegiatan pretest yaitu tes yang dilakukan sebelum menerapkan model pembelajaran explicit instruction sekitar $14,29 \%$ yang berada pada kategori sangat rendah dan $28,57 \%$ skor siswa yang 
berada pada kategori rendah. Selanjutnya, untuk ketuntasan hasil belajar siswa pada kegiatan pretest dan posttest dapat dilihat pada tabel 11 berikut.

Tabel 11. Deskripsi Ketuntasan Hasil Belajar Siswa pada Pretest dan Posttest

\begin{tabular}{cccccc}
\hline \multirow{2}{*}{ Skor } & \multirow{2}{*}{ Kategori } & \multicolumn{2}{c}{ Pretest } & \multicolumn{2}{c}{ Posttest } \\
\cline { 3 - 6 } & & f & \% & f & \% \\
\hline $0-69$ & Tidak Tuntas & 22 & 78,57 & 2 & 7,14 \\
\hline $70-100$ & Tuntas & 6 & 21,43 & 26 & 92,86 \\
\hline & Jumlah & 28 & 100 & 28 & 100 \\
\hline
\end{tabular}

Berdasarkan tabel di atas dapat dijelaskan bahwa hasil belajar pretest siswa sebelum diterapkan model pembelajaran explicit instruction mencapai $78,57 \%$ yang tidak tuntas. Dengan demikian, ketuntasan belajar siswa secara klasikal belum terpenuhi. Sementara, nilai posttest siswa setelah diterapkan model pembelajaran explicit instruction 92,86\% ketuntasan hasil belajar siswa berada pada kategori tuntas sehingga ketuntasan belajar siswa secara klasikal telah terpenuhi.

Selanjutnya digunakan adalah uji-t berkorelasi uji pihak kiri untuk menguji kebenaran hipotesis. Hipotesis yang akan diuji adalah:

$$
H_{0}: \mu_{1} \geq \mu_{2} \text { dan } H_{a}: \mu_{1}<\mu_{2}
$$

$H_{0}=$ Rata-rata hasil belajar pretest siswa lebih besar atau sama dengan rata-rata hasil belajar posttest siswa.

$H_{a}=$ Rata-rata hasil belajar pretest siswa lebih kecil dari rata-rata hasil belajar posttest siswa.

Kriteria pengujian hipotesis tersebut adalah $\mathrm{H}_{\mathrm{a}}$ diterima jika $\mathrm{t}_{\text {hitung }}>\mathrm{t}_{\text {tabel, }}$ jika $t_{\text {hitung }}<t_{\text {tabel }}$ maka $\mathrm{H}_{0}$ diterima dengan taraf signifikan $\mathrm{a}=0,05$. Berdasarkan hasil pengujian hipotesis penelitian dengan menggunakan uji-t berkorelasi uji pihak kiri diperoleh nilai $t_{\text {hitung }}$ sebesar 4,931 sedangkan nilai $\mathbf{t}_{\text {Tabel }}$ pada taraf signifikansi $a=0,05$ dan derajat kebebasan $(\mathrm{dk})=28-1=27$ adalah sebesar 1,703 .

Dari hasil analisis tampak bahwa nilai $t_{\text {hitung }}>t_{\text {tabel }}(4,931>1,703)$. Dengan demikian dapat disimpulkan bahwa hipotesis $\mathrm{H}_{\mathrm{a}}\left(\mathrm{H}_{\mathrm{a}}: \mu_{1}<\mu_{2}\right)$ diterima dan $\mathrm{H}_{\mathrm{O}}$ ditolak, jadi terdapat peningkatan nilai hasil belajar matematika siswa pada materi bilangan Romawi setelah mengikuti pembelajaran dengan menggunakan model pembelajaran explicit instruction.

Selanjutnya, untuk mengetahui peningkatan nilai pretest dan posttest maka digunakan indeks gain. Indeks gain dari penelitian ini dapat dilihat pada tabel berikut. 
Tabel 12. Deskripsi Indeks Gain Hasil Belajar Siswa

\begin{tabular}{ccccc}
\hline $\begin{array}{c}\text { Rata-Rata } \\
\text { Pretest }\end{array}$ & $\begin{array}{c}\text { Rata-Rata } \\
\text { Posttest }\end{array}$ & $\begin{array}{c}\text { Skor } \\
\text { Maksimum }\end{array}$ & $\begin{array}{c}\text { Indeks Gain } \\
\text { (d) }\end{array}$ & Kategori \\
\hline 55,32 & 83,29 & 100 & 0,62601 & Sedang \\
\hline
\end{tabular}

Berdasarkan hasil perhitungan indeks gain (d) diperoleh bahwa rerataan indeks gain yang diperoleh dari penelitian ini sebesar 0,62601 berada pada kategori sedang. Hal ini menunjukkan bahwa terjadi peningkatan hasil belajar siswa pada pembelajaran matematika materi bilangan Romawi setelah diajar dengan model pembelajaran explicit instruction.

Berdasarkan hasil penelitian dan analisis data mengenai perbandingan nilai statistik menunjukkan bahwa sejumlah sampel 28 siswa, nilai pretest untuk nilai terendah adalah 20 dan nilai tertinggi adalah 85 dari skor ideal 100. Nilai Posttest untuk nilai terendah 60 dan nilai tertinggi adalah 100 dari skor ideal 100. Rata-rata pretest 55,32 dan posttest 83,29 .

Perbandingan kategori hasil belajar berdasarkan hasil distribusi persentase skor nilai pretest dan posttest sebelum dan sesudah penggunaan model pembelajaran explicit instruction pada pembelajaran matematika materi bilangan Romawi menunjukkan bahwa pada kegiatan pretest persentase tertinggi terletak pada kategori tinggi dengan persentase hanya mencapai $32,14 \%$. Sementara pada kegiatan posttest persentase tertinggi juga terletak pada kategori tinggi akan tetapi persentase kategori tersebut mencapai 53,57\%. Hal ini mengindikasikan bahwa lebih dari setengah siswa mencapai skor yang berada pada kategori tinggi pada kegiatan posttesti dibandingkan dengan pretest kurang dari setengah siswa mencapai skor tersebut.

Perbandingan tingkat ketuntasan berdasarkan klarifikasi ketuntasan hasil belajar siswa, pada rentang skor 70-100 dinyatakan tuntas dan 0-69 dinyatakan tidak tuntas menunjukkan bahwa persentase kategori ketuntasan hasil belajar siswa pada proses pembelajaran matematika materi bilangan Romawi dengan penerapan model pembelajaran explicit intruction; (1) siswa yang berada pada kategori tidak tuntas pada pretest sebanyak 22 siswa dengan persentase $78,57 \%$ dan siswa yang tuntas sebanyak 6 siswa dengan persentase $21,43 \%$, (2) siswa yang berada pada kategori tidak tuntas pada posttest sebanyak 2 siswa dengan persentase $7,14 \%$ dan siswa yang tuntas pada posttest sebanyak 26 siswa dengan persentase $92,86 \%$.

Dari hasil pengujian hipotesis tersebut terlihat bahwa nilai $\mathrm{t}_{\text {hitung }}>\mathrm{t}_{\text {Tabel }}$ $(4,931>1,703)$. Dengan demikian, dapat disimpulkan bahwa hipotesis $\mathrm{H}_{0}$ 
ditolak, jadi terdapat perbedaan hasil belajar matematika siswa sebelum dan setelah mengikuti pembelajaran matematika pada materi bilangan Romawi dengan menggunakan model pembelajaran explicit instruction. Dengan demikian dapat dikemukakan bahwa terjadi peningkatan hasil belajar matematika siswa setelah diterapkan model pembelajaran explicit instruction.

Hal ini didukung dari hasil perhitungan indeks gain diperoleh dari siswa yaitu (a) terdapat 9 siswa yang berada pada indeks gain tinggi; (b) 19 siswa yang berada pada kategori indeks gain sedang; (c) tidak ada siswa yang masuk pada kategori indeks gain rendah dan (d) rerataan indeks gain yang diperoleh sebesar 0,62601 yang berada pada kategori sedang. Dari perhitungan indeks gain tersebut dapat disimpulkan bahwa terjadi peningkatan hasil belajar matematika pada pembelajaran matematika materi bilangan Romawi setelah diajar dengan menggunakan model pembelajaran explicit instruction.

Hasil penelitian ini sejalan dengan hasil penelitian yang dilakukan oleh (Darmiyati \& Hasanah, 2018) bahwa hasil belajar matematika siswa meningkat setelah diterapkan model pembelajaran explicit instruction dalam pembelajaran matematika. Selain itu, (Putri \& Afrom, 2018) menyatakan bahwa salah satu upaya peningkatan hasil belajar matematika siswa dilakukan dengan menerapkan model pembelajaran explicit instruction. Pemilihan model pembalajaran yang tepat dapat meningkatkan hasil belajar matematika siswa pada materi bilangan Romawi (Natalis \& Djuzairoh, 2014).

Pemilihan model pembelajaran explicit instruction sebagai salah satu model pembelajaran yang dapat diterapkan dalam pembelajaran matematika dilakukan karena model ini dapat mengajarkan suatu konten atau konsep matematika secara terstruktur (Pujiyati, 2017). Berdasarkan hasil penelitian ini, model pembelajaran sebagai salah satu faktor yang berkontribusi dalam menentukan prestasi atau keberhasilan belajar siswa dalam memahami atau mempelajari suatu konsep matematika olehnya itu diharapkan guru memiliki kreativitas dalam hal memilih metode pembelajaran yang tepat untuk membantu siswa. Dengan demikian, pemilihan model pembelajaran yang tepat dapat meningkatkan pemahaman dan kemampuan siswa dalam menguasai suatu materi ajar yang diajarkan di kelas.

\section{SIMPULAN}

Terdapat peningkatan hasil belajar matematika siswa setelah diterapkan model pembelajaran explicit instruction yang ditunjukkan dengan kategori rerataan hasil belajar di akhir pembelajaran berada pada kategori tinggi jika 
dibandingkan sebelum diterapkan model pembelajaran tersebut berada pada kategori rendah. Selain itu, peningkatan hasil belajar siswa juga diperoleh dari data hasil uji statistik dengan menggunakan rumus uji-t, perolehan $t_{\text {hitung }}$ sebesar 4,931 dengan $d k=n-1=28-1=27$ dan $\alpha=0,05$ sehingga diperoleh $t_{\text {tabel }}=1,703$. Jadi $t_{\text {hitung }}>t_{\text {tabel }}$ yaitu 4,931 $>1,703$, serta peningkatan hasil belajar matematika siswa yang diperoleh dari perhitungan indeks gain sebesar 0,62601 menunjukkan bahwa rata-rata hasil belajar dengan penerapan model pembelajaran explicit instruction berada pada kategori sedang. Dengan demikian dapat dikemukakan bahwa model pembelajaran explicit instruction dapat dijadikan sebagai salah satu acuan model pembelajaran dalam membelajarkan materi bilangan Romawi karena proses pembelajarannya yang terstruktur dalam mengenalkan konsep dan pemberian penguatan konsep agar pengetahuan konsep dapat mengendap dan bertahan lama dalam memori siswa.

Agar diperoleh deskripsi yang lebih lengkap terkait penerapan model pembelajaran explicit instruction dalam pembelajaran matematika di sekolah dasar, perlu dilakukan penelitian verifikasi dengan memilih materi yang lain, misalnya geometri, pengolahan data (statistik) dan masalah lainnya tentunya dengan tingkat kesulitan yang lebih tinggi. Selain itu, bisa juga memilih instrumen yang berbeda, misalnya pengajuan masalah bukan penyelesaian soal atau tes hasil belajar atau menggunakan tinjauan lain misalnya gaya belajar atau kemampuan matematika siswa.

\section{DAFTAR PUSTAKA}

Amir, M. F. (2018). pengembangan perangkat pembelajaran berbasis masalah kontekstual untuk meningkatkan kemampuan metakognisi siswa Sekolah Dasar. Journal of Mathematics Education IKIP Veteran Semarang, 2(1), 117-128. Retrieved from http://ejournal.ivet.ac.id/index.php/matematika/article/view/538

Basuki, \& Haryanto. (2014). Asesmen pembelajaran. Bandung: PT. Rosdakarya.

Darch, C., Gerten, D., \& Gersten, R. (1984). Explicit instruction in mathematics problem solving. The Journal of Educational Research, 77(6), 351-359. Retrieved from https:/ / www.tandfonline.com/doi/abs/10.1080/00220671.1984.108855 55

Darmiyati, D., \& Hasanah, R. N. (2018). Penerapan model explicit instruction dikombinasikan dengan model probing prompting dan media realita pada pembelajaran matematika di Sekolah Dasar. Jurnal Vidya Karya, 32(2), 139-147. Retrieved from https://ppjp.ulm.ac.id/journal/index.php/JVK/article/view/5231

Fatimah. (2009). Fun math matematika asyik dengan metode pemodelan. Bandung: DAR Mizan. 
Fraenkel, J. R., \& Wallen, N. E. (2003). How to design and evaluate research in education fifth edition book 2. New York: McGraw-Hill Companies.

Hake, R. (1999). Analyzing change/gain score. Indiana: Indiana University.

Heruman. (2012). Model pembelajaran matematika. Bandung: Remaja Rosdakarya.

Natalis, D., \& Djuzairoh, S. (2014). Pengaruh tipe stad terhadap hasil belajar pada materi bilangan romawi di Sekolah Dasar. Jurnal Pendidikan Dan Pembelajaran, 3(8), 1-12. Retrieved from http://jurnal.untan.ac.id/index.php/jpdpb/article/view/5945

National Mathematics Advisory Panel. (2008). Foundations for success: The final report of the national mathematics advisory panel. Washington, DC, USA: Department of Education.

Pham, H. (2011). Theory-based instructional models applied in classroom contexts. Literacy Information and Computer Education Journal, 2(2), 406415. Retrieved from http://infonomics-society.org/wpcontent/uploads/licej/published-papers/volume-2-2011/TheoryBased-Instructional-Models-Applied-in-Classroom-Contexts.pdf

Pujiyati, S. F. (2017). Penerapan model explicit instruction berbantuan media petak perkalian dalam materi ajar kelipatan dan faktor suatu bilangan. Jurnal Penelitian Tindakan Kelas, 18(1). Retrieved from http://www.irpp.com/index.php/didaktikum/article/view/665

Putri, D. D. M., \& Afrom, I. (2018). Upaya meningkatkan hasil belajar matematika dengan menggunakan model explicit instruction dan course review horay berbantu media manipulatif pada peserta didik kelas VB di SDN-3 Langkai Palangkaraya tahun pelajaran 2017/2018. Tunas: Jurnal Pendidikan Guru Sekolah Dasar, 4(1), 24-31. Retrieved from http://journal.umpalangkaraya.ac.id/index.php/tunas/article/view/4 97

Ramineni, C., \& Williamson, D. M. (2013). Automated essay scoring: Psychometric guidelines and practices. Assessing Writing, 18(1), 25-39. Retrieved from https://www.sciencedirect.com/science/article/pii/S107529351200047 5

Ratumanan, T.G., \& Laurens, T. (2011). Penilaian hasil belajar pada tingkat satuan pendidikan. Surabaya: Unesa University Press.

Sardiman, A. M. (2011). Interaksi dan motivasi belajar mengajar. Jakarta: Rajawali Press.

Stiff, L. V., \& Curcio, F. R. (1999). Developing mathematical reasoning in grades $k$ 12. United Stated of Amerika: General Year Book.

Sudjana, N. (2012). Penilaian hasil proses belajar mengajar. Bandung: Bandung: PT Remaja Rosdakarya.

Susanto, A. (2013). Teori belajar pembelajaran di Sekolah Dasar. Jakarta: Kencana Prenadamedia Group. 
Tim Penyusun Direntorat Pembinaan Sekolah Menengah Atas Dirjen Manajemen Pendidikan Dasar dan Menengah. (2011). Panduan pengembangan bahan ajar. Jakarta: Depdiknas.

University of Iowa. (2014). Evaluation and examination service. Preparing and Evaluating Essay Test Questions. Technical bulletin 36.

Widodo, T., \& Kadarwati, S. (2013). Higher order thinking berbasis pemecahan masalah untuk meningkatkan hasil belajar berorientasi pembentukan karakter siswa. Jurnal Cakrawala Pendidikan, 5(1). Retrieved from http://lppmp.uny.ac.id/sites/lppmp.uny.ac.id/files/15 Tri Widodo EDIT.pdf 